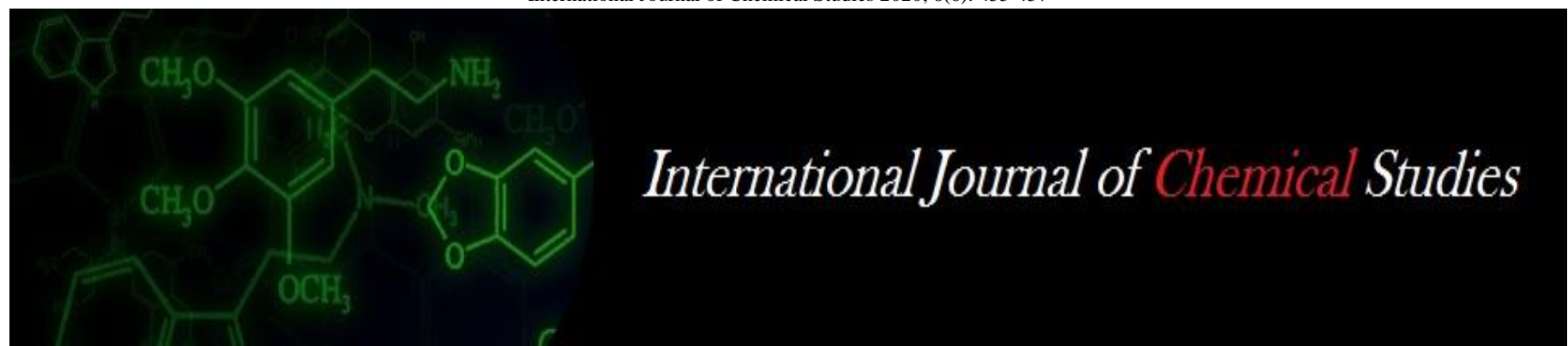

P-ISSN: 2349-8528

E-ISSN: 2321-4902

www.chemijournal.com

IJCS 2020; 8(6): 455-457

(C) 2020 IJCS

Received: 05-08-2020

Accepted: 12-09-2020

\section{Ashish Kumar}

Fruit Research Station,

Kuthulia, Rewa, Madhya

Pradesh, India

\section{SK Ray}

Directorate of Research, BCKV,

PO: Kalyani, Nadia, West

Bengal, India

\section{SV Kolase}

Department of Horticulture,

Mahatma Phule Krishi

Vidyapeeth, Rahuri, Dist.

Ahmednagar, Maharashtra,

India

K Jyothirmai Madhavi

Fruit Research Station,

Sangareddy, Dist. Medak,

Telangana, India

\section{Hemant Sharma}

Agricultural Experimental

Station, NAU, Paria, Valsad,

Gujarat, India

\section{MB Dalavi}

Regional Fruit Research Station, Vengurle, Sindhudurg,

Maharashtra, India

\section{RA Raut}

Regional Fruit Research Station,

Vengurle, Sindhudurg,

Maharashtra, India
Corresponding Author:

Ashish Kumar

Fruit Research Station,

Kuthulia, Rewa, Madhya

Pradesh, India

\section{Management of blossom blight and anthracnose disease of mango caused by Colletotrichum gloeosporioides}

\author{
Ashish Kumar, SK Ray, SV Kolase, K Jyothirmai Madhavi, Hemant \\ Sharma, MB Dalavi and RA Raut
}

DOI: https://doi.org/10.22271/chemi.2020.v8.i6g.10810

\begin{abstract}
In the present investigation, efforts were made to evaluate different fungicides against blossom blight and anthracnose of mango at different AICRP $(\mathrm{F})$ centres in India. From the five years pooled data, it was observed that carbendazim + mancozeb $(0.2 \%)$ were the most effective in controlling blossom blight and anthracnose disease of mango at Mohanpur, Rahuri, Rewa and Paria centres. At Sangareddy, on the other hand, chlorothalonil $(0.2 \%)$ was found to be effective controlling anthracnose of mango. At Vengurle, carbendazim $(0.1 \%)$ was found to be effective in the management of blossom blight and anthracnose of mango. It is thus concluded that spraying of carbendazim+ mancozeb $(0.2 \%)$ or carbendazim $(0.1 \%)$ thrice at 10 days interval, starting from the initiation of the disease symptoms was found to be the most effective for management of blossom blight and anthracnose of mango.
\end{abstract}

Keywords: Anthracnose, blossom blight, Colletotrichum gloeosporioides, fungicides, Mangifera indica

\section{Introduction}

Mango (Mangifera indica L.), which is known as the national fruit of India, occupies nearly half of the total area under fruits cultivation in the country. In the world mango production scenario, India shares about 56 percent of the total production. However, this productivity is affected by various diseases. Although mango is affected by a large number of diseases, blossom blight and anthracnose, which are caused by Colletotrichum gloeosporioides, are of greater significance because of the economic repercussions of reduced flower sets and yield losses in mango due to the disease. It was seen that the co-incidence of rains or heavy fog during flowering tended to increase the disease incidence manifold. Early symptoms of blossom blight included inflorescence wilting and production of minute black spots, which later enlarged and coalesced, resulting in shedding of flowers and shrivelling and drying of flower axes. The affected inflorescence then turned dark brown to greenish black, and failed to set fruits. However, the severity of the disease was seen to be greatly dependent on environmental factors that contributed to induced stress on trees during inflorescence development (Lonsdale, 1993) ${ }^{[4]}$. Foliar anthracnose of mango, which is caused by Colletotrichum gloeosporioides is another most damaging pre-harvest disease that was seen in all mango producing areas. It caused damage to foliage and under crowded and moist conditions, caused serious problems in nurseries and young orchards (Udhaya Kumar and Rani, 2010) ${ }^{[6]}$. It also caused flower set reduction, which resulted in yield losses in mango. In recent years, the mango growers have faced problems in controlling this disease with fungicides because the pathogen appears to have developed resistance. Hence, a study was undertaken to evaluate the efficacy of different fungicides against blossom blight and foliar anthracnose of mango caused by Colletotrichum gloeosporioides.

\section{Materials and Methods}

The trial was conducted at different locations and at different AICRP (F) centres in India Regional Fruit Research Station, Vengurle (Maharashtra), Mahatma Phule Krishi Vidyapeeth, Rahuri (Maharashtra), Agricultural Experimental Station, Paria (Gujarat), Bidan Chandra Krishi Vidyapeeth, Mohanpur (West Bengal), Fruit Research Station, Rewa (MP) and 
Fruit Research Station, Sangareddy (AP).

The efficacy of seven fungicides (carbendazim @ $0.1 \%$, thiophanate methyl @ $0.1 \%$, mancozeb @ $0.2 \%$ chlorothalonil @0.2\%, tricyclazole@0.1\%, carbendazim + mancozeb@0.2\% and propineb @ 0.2\%) was evaluated in R B D with three replications. The fungicides were sprayed thrice at 10 days interval, starting from the initiation of the disease symptoms in mango tree leaves and inflorescence. Disease incidence was recorded on 100 leaves/treatment (for anthracnose) and 100 inflorescence/treatment (for blossom blight) that were randomly selected before the beginning of the first spray of fungicides. Subsequent observations were recorded after 10 days of each spray. Disease severity was assessed by using a scale of $0-5$, where $0=$ No incidence; 1 $=1-20 \%$ incidence; $2=21-40 \%$ incidence; $3=41-60 \%$ incidence; $4=61-80 \%$ incidence and $5=81-100 \%$ incidence. Percent Disease Index (PDI) was calculated by using following formula:

$$
\mathrm{PDI}=\frac{\text { Sum of all numerical rating }}{\text { No. of leaves } / \text { panicles observed } \times \text { Maximum rating }} \times 100
$$

\section{Results and Discussion}

Field trials were conducted at different AICRP $(\mathrm{F})$ centres in India. The set of seven fungicides was evaluated at their respective concentrations against blossom blight and anthracnose of mango. It was observed from the five years pooled data that all the fungicides, at their given concentration, when sprayed thrice at ten days interval, effectively controlled the incidence of blossom blight and anthracnose of mango at all centres as compared to control.

Among the various fungicides, carbendazim + mancozeb $(0.2 \%)$ was found to be highly effective at Mohanpur, Rahuri and Rewa against blossom blight of mango with a mean PDI of $3.14 \%, 4.13 \%$ and $7.66 \%$, respectively. At Vengurle, on the other hand, carbendazim $(0.1 \%)$ and tricyclazole $(0.1 \%)$ were found to be effective in controlling blossom blight with a mean PDI of $10.88 \%$ (Table 1).

Table 1: Efficacy of different fungicides against blossom blight of mango

\begin{tabular}{|c|c|c|c|c|}
\hline \multirow{2}{*}{ Treatments } & \multicolumn{4}{|c|}{ Percent Disease Incidence } \\
\cline { 2 - 5 } & Mohanpur & Rahuri & Rewa & Vengurle \\
\hline Carbendazim (0.1\%) & 7.18 & 15.89 & 10.33 & 10.88 \\
$(14.81)^{*}$ & $(21.77)$ & $(18.74)$ & $(19.07)$ \\
\hline Thiophanate methyl & 6.37 & 14.02 & 15.75 & 12.08 \\
$(0.1 \%)$ & $(14.25)$ & $(21.64)$ & $(23.38)$ & $(20.25)$ \\
\hline Mancozeb (0.2\%) & 8.19 & 15.44 & 11.49 & 17.33 \\
& $(16.28)$ & $(22.83)$ & $(19.81)$ & $(24.43)$ \\
\hline Chlorothalonil (0.2\%) & 3.46 & 8.42 & 19.90 & 18.24 \\
$(10.60)$ & $(16.31)$ & $(26.49)$ & $(25.20)$ \\
\hline \multirow{2}{*}{ Propineb (0.2\%) } & 3.68 & 13.04 & 12.53 & 12.74 \\
& $(10.69)$ & $(20.67)$ & $(20.73)$ & $(20.84)$ \\
\hline Carbendazim (12\%)+ & $3.14(9.46)$ & 4.13 & 7.66 & 14.78 \\
Mancozeb (63\%) (0.2) & & $(11.46)$ & $(16.06)$ & $(22.60)$ \\
\hline \multirow{2}{*}{ Tricyclazole (0.1\%) } & 4.56 & 10.39 & 9.10 & 10.88 \\
& $(11.32)$ & $(18.91)$ & $(17.55)$ & $(19.07)$ \\
\hline Control & 29.22 & 45.67 & 36.07 & 28.37 \\
& $(32.48)$ & $(42.48)$ & $(36.91)$ & $(32.06)$ \\
\hline SEm ( \pm$)$ & 1.50 & 0.94 & 1.05 & 0.81 \\
\hline CD at 5\% & 4.35 & 2.88 & 3.15 & 2.44 \\
\hline
\end{tabular}

*Figures in parenthesis are arc sin value.

The pooled data (Table 2) revealed that, among the different treatments, foliar spray with carbendazim + mancozeb $(0.2 \%)$ was the most effective for controlling anthracnose at
Mohanpur, Paria and Rewa with a mean PDI of $6.16 \%, 8.37 \%$ and $6.06 \%$, respectively. At Sangareddy, chlorothalonil $(0.2 \%)$ was found to be effective with a mean PDI of $8.80 \%$, whereas at Vengurle, carbendazim $(0.1 \%)$ was found to be effective in controlling anthracnose of mango with a mean PDI of $9.81 \%$. Kumar (2014) ${ }^{[3]}$ reported that three sprays of carbendazim + mancozeb at 10 days interval, starting from the initiation of disease symptoms was the most effective in controlling foliar anthracnose of mango cv. Dashahari. Singh (2013) ${ }^{[5]}$ recorded minimum incidence of post-harvest fruit rot when fruits treated with hot water supplemented with thiophanate methyl $(0.1 \%)$ or carbendazim $(0.1 \%)$. Gajbhiye et al. (2000) ${ }^{[1]}$ reported that carbendazim @ 0.05\% reduced post-harvest rot and showed no residues as well. Venkataravanappa and Nargund (2008) ${ }^{[7]}$ also reported that carbendazim $(0.1 \%)$ was the most effective in managing anthracnose in mango. Kumar and Solanki (2014) ${ }^{[2]}$ reported that three sprays of carbendazim + mancozeb $(0.2 \%)$ proved to be the most efficient in reducing the severity of blossom blight and anthracnose in mango under field conditions.

Table 2: Efficacy of different fungicides against anthracnose of mango

\begin{tabular}{|c|c|c|c|c|c|}
\hline \multirow{2}{*}{ Treatments } & \multicolumn{5}{|c|}{ Percent Disease Incidence } \\
\hline & Mohanpur & Paria & Rewa & Sangareddy & Vengurle \\
\hline $\begin{array}{r}\text { Carben } \\
(0.1\end{array}$ & & \begin{tabular}{|c|}
9.70 \\
$(18.06)$
\end{tabular} & \begin{tabular}{|c|}
9.12 \\
$(16.53)$
\end{tabular} & $\begin{array}{c}14.42 \\
(22.28)\end{array}$ & \\
\hline $\begin{array}{l}\text { Thiol } \\
\text { methy }\end{array}$ & & & & & \\
\hline Mancc & $\begin{array}{c}17.68 \\
(24.56) \\
\end{array}$ & & & $\begin{array}{r}13 . \\
(20 . \\
\end{array}$ & \\
\hline Chlor & & $\begin{array}{l}13.36 \\
(21.36) \\
\end{array}$ & & $\begin{array}{r}8.8 \\
(17 .\end{array}$ & \\
\hline Prop & 9.23 & \begin{tabular}{|l|}
13.92 \\
$(21.83)$ \\
\end{tabular} & \begin{tabular}{|c|}
8.27 \\
$(15.70)$ \\
\end{tabular} & $\begin{array}{c}13.73 \\
(21.70) \\
\end{array}$ & $\begin{array}{c}10.28 \\
(18.64) \\
\end{array}$ \\
\hline $\begin{array}{c}\text { Carbendazim } \\
(12 \%)+\text { Mancozeb } \\
(63 \%)(0.2)\end{array}$ & $\begin{array}{c}6.16 \\
(13.56)\end{array}$ & $\begin{array}{c}8.37 \\
(16.62)\end{array}$ & $\begin{array}{c}6.06 \\
(12.92)\end{array}$ & $\begin{array}{c}11.00 \\
(19.34)\end{array}$ & $\begin{array}{c}13.44 \\
(21.22)\end{array}$ \\
\hline $\begin{array}{r}\text { Tricy } \\
\quad 0 \\
\end{array}$ & $\begin{array}{c}10.50 \\
(18.22) \\
\end{array}$ & $\begin{array}{c}12.03 \\
(20.16) \\
\end{array}$ & \begin{tabular}{|l|}
15.93 \\
$(21.69)$ \\
\end{tabular} & $\begin{array}{c}9.91 \\
(18.30) \\
\end{array}$ & $\begin{array}{c}12.21 \\
(20.27) \\
\end{array}$ \\
\hline & $\begin{array}{c}53.25 \\
(46.85)\end{array}$ & $\begin{array}{l}40.14 \\
(39.29) \\
\end{array}$ & $\begin{array}{l}28.07 \\
(30.32) \\
\end{array}$ & $\begin{array}{c}27.63 \\
(31.25)\end{array}$ & $\begin{array}{c}33.76 \\
(35.46) \\
\end{array}$ \\
\hline & 0.323 & 0.40 & 1.11 & 1.54 & 0.95 \\
\hline $\mathrm{CD}$ at $5 \%$ & 0.906 & 1.12 & 3.33 & 4.43 & 2.65 \\
\hline
\end{tabular}

*Figures in parenthesis are arc sin value

\section{Conclusion}

Based on five years pooled data, it was concluded that three sprays of carbendazim + mancozeb $(0.2 \%)$ was the most effective treatment for reducing the severity of blossom blight and anthracnose disease in mango. Carbendazim $(0.1 \%)$ was observed to be the second best fungicide for control of blossom blight and anthracnose in mango.

\section{Acknowledgement}

This work was carried out with financial support from the Indian Council of Agricultural Research (ICAR) and the collaborative organizations (SAUs/ICAR Institutes) under the ICAR-All India Coordinated Research Project (AICRP) on Fruits. The authors wish to acknowledge the support of the ICAR and the collaborative organizations in providing the requisite research facilities.

\section{References}

1. Gajbhiye VT, Singh R, Kumar RH, Singh CP. Efficacy of post-harvest treatment of carbendazim against stem 
endrot/anthracnose disease of mango. Ann. Pl. Protec. Sci. 2000; 8:230-232.

2. Kumar, Ashish, Solanki, Shiv Charan. Management of blossom blight and leaf anthracnose of mango using fungicides. Internat. J. Plant Protec. 2014; 7(2):453-455.

3. Kumar, Ashish. Management of anthracnose disease of mango by pre and post-harvest treatments. Ann. Pl. Protec. Sci. 2014; 22:390-394.

4. Lonsdale JH. Mango diseases in South Africa. South African Mango Growers' Association Yearbook. 1993; 13:89-92.

5. Singh AK. Management of post-harvest anthracnose disease of mango by pre and post-harvest treatments. Ann. Pl. Protec. Sci. 2013; 21:446-447.

6. Udhaya Kumar R, Usha Rani S. Epidemiological and nutritional factors on growth of Colletotrichumglo eosporioides. Ann. Pl. Protec. Sci. 2010; 18:159-163.

7. Venkataravanappa V, Nargund VB. Sensitivity of mango anthracnose to fungicide. Ann. Pl. Protec. Sci. 2008; $16: 244-246$ 